\title{
PENDIDIKAN DAN BIMBINGAN KEGAKAPAN HIDUP (LIFE SKILL) PESERTA DIDIK
}

\author{
Mislaini \\ Sekolah Tinggi Agama Islam (STAI), YPI Al-Ikhlas Painan \\ Jl. Parak Gadang No.005 Nagari Sago (Depan Terminal Sago) Kecamatan \\ IV Jurai Kabupaten Pesisir Selatan, Padang Sumatera Barat \\ Email:mislaini0@gmail.com
}

\begin{tabular}{|c|c|c|}
\hline Diterima: 10 Maret 2017 & Revisi:20 April 2017 & Disetujui: 5 Mei 2017 \\
\hline
\end{tabular}

\begin{abstract}
Education must reflect the values of everyday life, both preservative and progressive. So that educational institutions should merge with real-life values that exist in the environment. For this reason life skill education (life skill) undoubtedly to be applied and applied for students in any educational institutions tingakat. The development of life skills values in various activities in educational institutions both in classroom learning, as well as in extracurricular activities, and in religious activities is expected to foster unyielding spirit with high work ethic, creative independence, innovative in creating works in all Field, so that in the end able to create human resources that qualified for the surrounding community.
\end{abstract}

Keywords : life skills education, creative and innovative, and educational institutions

\begin{abstract}
Abstrak
Pendidikan harus merefleksikan nilai-nilai kehidupan sehari-hari, baik yang bersifat preservatif dan progresif. Sehingga lembaga pendidikan mestinya menyatu dengan nilai-nilai kehidupan nyata yang ada di lingkungannya. Untuk itulah pendidikan kecakapan hidup (life skill) niscaya untuk diterapkan dan diaplikasi bagi peserta didik di lembaga pendidikan tingakat manapun. Pengembangan nilai-nilai kecakapan hidup dalam berbagai kegiatan di lembaga pendidikan baik dalam pembelajaran di kelas, maupun dalam kegiatan ekstrakurikuler, serta
\end{abstract}


dalam kegiatan keagamaan diharapkan dapat menumbuhkan jiwa pantang menyerah dengan etos kerja yang tinggi, mandiri kreatif, inovatif dalam menciptakan karya-karya di segala bidang, sehingga pada akhirnya mampu menciptakan sumber daya manusia yang mumpuni bagi masyarakat sekitarnya.

Kata kunci : pendidikan kecakapan hidup, kreatif dan inovatif, dan lembaga pendidikan

\section{A. Pendahuluan}

Kondisi perkembangan pendidikan yang ada selama ini, khususnya yang ada di negara kita - menuntut kepada semua pihak, baik para pendidik dan steakholder untuk melakukan perubahan dalam pendekatan pengajarannya yang terasa masih konvensional dan bersifat doktrinal semata-mata. Sejauh ini masih banyak di daerah-daerah yang tampak memposisikan para murid sebagai objek pendidikan. Hal ini juga terjadi pula di tingkat perguruan tinggi. Padahal peserta didik sesungguhnya merupakan makhluk yang sama sekali berbeda dengan hewan. Ada banyak potensi yang telah diberikan Allah kepada manusia, yang dalam hal ini peserta didik terlewatkan begitu saja.

Posisi guru dan dosen saat mentransfer pengetahuan kepada para murid dan mahasiswa, terkadang masih lupa bahwa posisi peserta didik sebagai subjek pendidikan menjadi terabaikan. Hal ini dikarenakan mereka menuntut peserta didik yang ada harus menguasai teori-teori seperti yang dimilikinya, yang sering kali pula tanpa ada aplikasi yang nyata untuk menumbuhkembangkan kecakapan hidup (life skills) dalam kehidupan nyata. Sehingga murid terkesan seperti Bank yang hanya di gunakan untuk penyimpanan ilmu pengetahuan.

Sebagaimana dipahami bersama, bahwa dalam kontek kekinian, pendidikan sebagaimana dimaksud di atas (pendidikan selayaknya sebuah bank), jika ditelisik dengan kacapandang yang lebih luas dan mendalam sangat mengesampingkan aspek-aspek manusiawi dan dan membuat peserta didik menjadi kerdil serta tidak kreatif. Hal ini disebabkan kelas hanya dikuasai guru/ 
dosennya. Untuk itulah di sini perlu dikembangkan sistem yang diterapkan dengan mengembangkan life skills, yakni sebuah sistem pendidikan dimana kecakapan hidup menjadi hal yang perlu ditumbuh-kembangkan dalam setiap peserta didik. Sehingga pada saatnya mereka menjadi bagain dari masyarakat yang mampu berfikir dan bertindak secara dewasa, kritis, berakhlak dalam menyikapi kehidupan, dapat memberi kontribusi positif serta tetap survive di tengah-tengah kehidupan pada zamannya.

Pada prinsipnya pengembangan kecakapan hidup adalah bagaimana seseorang dapat mengaktifkan dan menggerakkan semua nilai-nilai positif dan kompetensi yang dimiliki secara maksimal untuk diimplementasikan dalam mempertahankan hidup sehari-hari. Oleh sebab itu, pada artikel ini penulis ingin mendeskripsikan tentang pendidikan dan bimbingan kecakapan hidup (life skill) pada peserta didik yang selama ini cenderung diabaikan oleh kita semua.

\section{B. Pendidikan Kecakapan Hidup (Life Skill): Mengungkap Landasan Historis, Filosofis dan Yuridisnya}

\section{Landasan Historis}

Berkaitan dengan landasan pendidikan kecakapan hidup (life skill), pada dasarnya manusia sebagai makhluk yang ada di muka bumi ini akan selalu berusaha mempertahankan hidupnya. Hal tersebut minimal terletak pada orientasi manusia ke arah tiga hubungan yang sering dilakukan. Sebagaimana telah dikemukakan oleh Arifin, yang meliputi;

a) Hubungan manusia dengan penciptanya, yaitu Tuhan sekalian alam.

b) Hubungan dengan sesama manusia.

c) Hubungan dengan alam sekitar. Hal ini meliputi dari berbagai unsur kehidupan, seperti tumbuh-tumbuhan, binatang dan kekuatan alamiah yang ada. ${ }^{1}$

1 M. Arifin, Ilmu Pendidikan Islam, (Jakarta: Bumi Aksara, 1996), h. 1-2. 
Berdasarkan pada ketiga prinsip hubungan yang dibangun sebagaimana tersebut di atas, maka pada akhirnya manusia mengembangkan proses pertumbuhan kehidupan dan kebudayaan. Oleh sebab itu, ada posisi ini manusia sebagai makhluk Tuhan yang telah dianugerahi Allah kemampuan-kemampuan dasar yang bersifat rohaniah dan jasmaniah, agar dengannya manusia mampu mempertahankan hidup serta memajukan kesejahteraanya. Kemampuan dasar manusia ini dalam sepanjang sejarah pertumbuhannya menjadi modal dasar untuk mengembangkan kehidupannya di segala bidang.

Adapun sarana utama yang dibutuhkan untuk mengembangkan kehidupan manusia tidak lain dan tidak bukan adalah pendidikan, dalam dimensi yang setara dengan tingkat daya cipta, daya rasa dan daya karsa masyarakat serta anggota-anggotanya. Oleh karena itu, antara manusia dan tuntutan hidupnya saling berpacu berkat dari dorongan ketiga daya tersebut, maka pendidikan menjadi semakin penting. Bahkan boleh dikatakan pendidikan merupakan kunci dari segala bentuk kemajuan hidup umat manusia sepanjang sejarah.

Pada prinsipnya, pendidikan berkembang dari perihal yang sangat sederhana (primitive) yang berlangsung dari zaman dimana manusia masih berada dalam ruang lingkup kehidupan yang serba sederhana. Sehingga, tujuan-tujuan yang ada dalam pendidikan pada tahap tersebut amat terbatas pada hal-hal yang bersifat survival. Selain itu tujuan tersebut juga masih terbatas pada bagaimana caranya memiliki keterampilan membuat alat-alat untuk mencari dan memproduksi bahan-bahan kebutuhan hidup, beserta pemeliharaanya, serta disesuaikan dengan kebutuhannya. Berbeda halnya ketika manusia semakin berbudaya dengan tuntutan hidup yang semakin tinggi dan komplek, maka pendidikan ditujukan bukan 
hanya pada pembinaan keterampilan, namun kepada pengembangan kemapuan-kemampuan teoritis dan praktis berdasarkan konsep-konsep berfikir ilmiah. ${ }^{2}$ Dengan kata lain, masalah kehidupan dan fenomena alam kemudian diupayakan dapat dijelaskan secara keilmuan.

Membahas mengenai persoalan pendidikan pada hakekatnya merupakan persoalan yang berhubungan langsung dengan kehidupan manusia yang sangat dinamis. ${ }^{3}$ Dengan demikian maka dapat dikatakan jika pendidikan merupakan salah satu instrumen, sel dan unsur dari aspek sosial budaya yang berperan sangat strategis dalam pembinaan suatu keluarga, masyarakat, atau bangsa. Berdasarkan atas kestrategisan fungsi dan keberperanan pendidikan di tengah-tengah masyarakat, maka perlu diupayakan dan dilaksanakan secara sadar, sistematis, terarah dan terpadu.

Oleh sebab itu, membangun kecakapan hidup seseorang sama halnya membangun sikap dan perilaku seseorang. Tidak jauh berbeda, pendidikan karakter adalah membangun watak, tabiat, akhlak, atau kepribadian seseorang yang terbentuk dari hasil internalisasi berbagai kebajikan yang diyakini dan digunakan sebagai landasan untuk cara pandang, berpikir, bersikap, dan bertindak. Untuk itulah maka memanusiakan peserta didik serta menjadikan mereka sebagai khalifah dimuka bumi dengan berbekal kecakapan hidup (life skill) adalah agenda dan proyek yang sesungguhnya yang perlu diperhatikan oleh kita semua.

\section{2. "Mazhab" Konstruktivisme:SebuahEmbrioLandasanFilosofisPendidikan Life Skill}

Secara filosofis alur ataupun skema pembelajaran dilakukan sesuai dengan rangkaian kurikulum yang telah dipersiapkan. Sehingga dalam implementasinya, aktivitsa pembelajaran selalu mengikuti buku teks yang ada dan sesuai dengan anjuran dari pemerintah. Maka tidak mengherankan

2 Ibid., h. 2-3.

3 Pada prinsipnya pendidikan selalu mengalami perubahan serta perkembangan sesuai dengan kehidupan tersebut baik secara teori maupun secara konsep oprasionalnya. Lebih lengkap lihat dalam Munzir Hitami, Mengonsep Kembali Pendidikan Islam, (Riau: Infinite Press, 2004), h. 1. 
jika dalam pembelajaran memiliki tujuan yang spesifik dan general, sehingga tujuan pembelajaran biasanya menitiktekankan paad pengetahuan. Dan seseorang dapat dikatakan telah belajar apabila telah mampu mengungkap dan me-review kembali sesuatu yang telah di pelajari sebelumnya. Sehingga, paradigma demikian menurut "madzhab" konstruktivistik berbeda dengan faham klasik, pengetahuan itu adalah bentukan (konstruksi) siswa sendiri yang sedang belajar. ${ }^{4}$

Dengan istilah lain dapat dikatakan jika manusia menciptakan atau membangun pengetahuan tersebut dengan cara mencoba memberi arti pada pengetahuan sesuai dengan pengalamannya. Hal ini sesuai dengan apa yang telah diungkapkan oleh Nurhadi dan Senduk, jika pengetahuan itu rekaan dan tidak stabil, sebab itulah pengetahuan merupakan konstruksi manusia dan secara konstan manusia mengalami pengalaman-pengalaman baru, maka pengetahuan itu tidak pernah stabil. Berdasarkan hal tersebut, maka pemahan yang kita peroleh cenderung bersifat tentatif dan tidak lengkap, sehingga pemahaman ini akan mendalam dan kuat jika diuji melalui pengalaman-pengalaman baru. ${ }^{5}$

Seyogjanya, di dalam proses pembelajaran, arahan guru merupakan bahan atau material yang harus diolah dan dirumuskan lagi oleh para peserta didik sendiri. Ketidakaktifan peserta didik dalam mempelajari, mencerna dan mengelola materi yang telah disampaikan, maka dapat dimungkinkan tidak akan menjadi tahu. Melihat hal demikian, maka ranah pendidikan ataupun pengajaran harus dapat membantu para peserta didik aktif belajar secara mandiri. Sementara itu dilain sisi, pengetahuan akan muncul dan dapat terbentuk melalui proses sosial. Menyikapi hal tersebut, Vygotsky dalam Suparno mendeskripsikan jika pengetahuan anak dapat dibentuk melalui kerjasama dengan orang lain atau teman-temanya. ${ }^{6}$

\footnotetext{
4 Paul Suparno, Reformasi Pendidikan Sebuah Rekomendasi, (Jakarta: Kanisius, 2000), h. 15.

5 Nurhadi and Agus Gerrad Senduk, Pembelajaran Konstektual Dan Penerapannya Dalam KBK, (Malang: Universitas Negeri Malang, 2004), h. 33.

6 Dalam hal ini telah dijelaskan bahwa kerjasama dengan orang lain dapat berlaku pada pembelajaran bahasa. Orang akan hanya bisa lebih maju dalam bidang bahasa bila ia belajar bersama
} 
Beranjak pada konsepsi yang telah teruarai diatas, maka pendidikan ataupun pembelajaran seyogjanya didesain dan dikemas menjadi sebuah proses yang mengkontruksi, namun bukan dan tidak hanya menerima sebuah pengetahuan semata. Disinilah idealnya para peserta didik dapat berperan aktif secara mandari untuk membangun pengetahuannya. Sehingga peserta didik akan menjadi pusat kegiatan, bukan guru. Adapun bentuk pembelajaran yang ideal adalah pembelajaran siswa yang aktif dan kritis. Proses inilah yang kemudian dalam diri peserta didik tidak boleh kosong, akan tetapi sudah memiliki pengertian awal tertentu, yang kemudian dibantuk untuk dikembangkan. Maka model yang sesuai dan cocok adalah model dialogal, model konsistensi, model mencari bersama antara siswa dan guru. ${ }^{7}$

Memperhatian uraian tersebut diatas, sekiranya dapat dikatakan jika model pembejalaran yang baik adalah model demokratis dan dialogis. Dalam kontek pendidikan Islam, pada dasarnya telah di jelaskan secara gambalang oleh Allah swt di dalam al-Quran, bahwa terdapat proses pendidikan dan pembelajaran tentang ketahuhidan yang dilakukan Allah sendiri kepada seluruh manusia ketika masih di alam ruh justru bukan dengan model dogma, akan tetapi nampak jelas di sini Allah menggambarkan metode dialog sehingga suasana nampak aktif. Hal ini terindikasi bahwa proses pendidikan sebenarnya sudah berlangsung sebelum manusia di hadirkan di muka bumi ini dengan cara dialog sebagaimana termaktub dalam QS. Al-A'raf 172, yang berbunyi:

orang lain. Maka, Vygotsky menekankan pentingnya dalam kerja sama, studi kelompok. Dalam studi kelompok itu siswa dapat saling mengoreksi, mengungkapkan gagasan, dan saling meneguhkan. Peran guru atau pendidik dalam aliran konstuktivisme ini adalah sebagai fasilitator atau moderator. Tugasnya adalah merangsang, membantu siswa untuk mau belajar sendiri, dan merumuskan pengertiannya. Guru juga mengevaluasi apakah gagasan siswa itu sesuai dengan gagasan para ahli atau tidak, sedangkan tugas siswa adalah aktif belajar dan mencerna. Lebih lengkap lihat dalam Suparno, Reformasi Pendidikan Sebuah Rekomendasi, h. 16.

7 Ibid. 


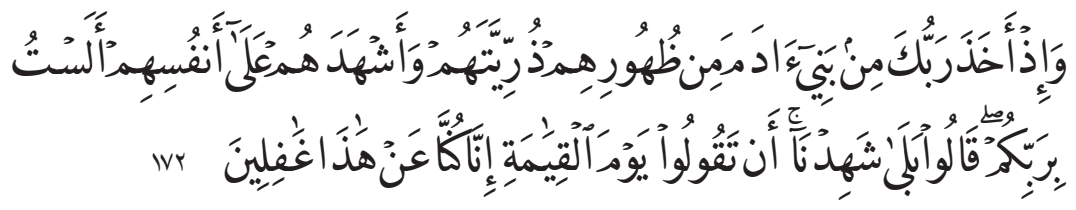

Artinya:

dan (ingatlah), ketika Tuhanmu mengeluarkan keturunan anak-anak Adam dari sulbi mereka dan Allah mengambil kesaksian terhadap jiwa mereka (seraya berfirman): "Bukankah aku ini Tuhanmu?" mereka menjawab: "Betul (Engkau Tuban kami), Kami menjadi saksi". (kami lakukan yang demikian itu) agar di hari kiamat kamu tidak mengatakan: "Sesungguhnya Kami (Bani Adam) adalah orang-orang yang lengah terhadap ini (keesaan Tuhan)".

Dengan mengaplikasikan kedua model tersebut, peserta didik tersebut diharapkan akan mampu menuangkan ide dan gagasannya. Selain itu, peserta didik juga mampu mengkritik ide ataupun pendapat guru yang dianggap tidak tepat. Dan yang lebih lagi diharapkan para peserta didik mampu mengungkapkan pendapat ataupun jalan pikiran yang berbeda dari gurunya. Pada posisi inilah guru tidak menjadi diktator ataupun menjadi pusat (centre oriented) dari peserta didik yang hanya menekankan satu nilai (value), satu jalan keluar, tetapi lebih bersifat demokratis. Oleh sebab itu, model pendidikan yang membuat siswa "bisu" (budaya bisu) tidak zamannya lagi. Adapun pendidikan yang benar-benar sesuai dengan asasi (fitrah) manusia haruslah membebaskan peserta didik dan tidak menjadikan mereka seperti mekanis atau robot tetapi diharapkan menjadi pribadi yang dapat berpikir, memilih, dan menentukan sikap.

Pada "madzhab" konstruktivisme memiliki landasan berfikir yang berbeda dengan "madzhab" atau pandangan dari kaum objektivisme dalam menentukan tujuan pembelajaran. Kaum objektivisme lebih menekankan pada hasil pembelajaran yang berupa pengetahuan. Menurut pandangan konstruktivistik, starategi mendapatkan porsi yang besar atau lebih diutamakan bila dibandingkan dengan "startegi" seberapa banyak 
siswa memperoleh dan mengingat pengetahuan. Bila merujuk pada faham konstruktivisme, maka guru memiliki tugas menfasilitasi proses dan kegiatan pembelajaran dengan cara-cara sebagai berikut, yaitu: (1) Menjadikan pengetahuan bermakna dan relevan bagi siswa; (2) Memberi kesempatan siswa menemukan dan menerapkan idenya sendiri; dan (3) Menyadarkan siswa agar menerapkan strategi mereka sendiri dalam belajar. ${ }^{8}$

Selanjutnya, untuk melengkapi penjelasan di atas, maka pada dasarnya dalam pandangan konstruktivisme, pengetahuan tumbuh dan berkembang melalui pengalaman, maka dalam hal ini ada empat konsep dasar Jean Piaget dalam Marwiyah yang dapat diaplikasikan pada pendidikan dalam berbagai bentuk dan bidang studi, yang berimplikasi pada organisasi lingkungan pendidikan, isi kurikulum, dan urutan-urutannya, metode mengajar, dan evaluasi. Adapun keempat konsep dasar tersebut menurut Piaget dalam Marwiyah yaitu: (a) Skemata, (b) Asimilasi, (c) Akomodasi, dan (d) Ekuilibrium (keseimbangan). ${ }^{9}$

Pendidikan sebagai sebuah sistem, pada dasarnya merupakan sistemasi dari proses pengalaman pendidikan. Oleh sebab itu, memanusiakan peserta didik dengan memposisikannya sebagai subjek pendidikan harus menjadi proyeksi baru dikalangan dunia pendidikan di negara kita. Sehingga para pendidikyang ada tidak seharusnya terus mengkonstruk image pada peserta didiknya bahwa dirinya satu-satunya agent of knowledge.

Walaupun sebenarnya keberadaan sang pendidik dimungkinkan mengungguli peserta didiknya. Namun demikian, akan menjadi lebih baik, apabila sang pendidik memposisikan sebagai sahabat dengan peserta didiknya, sehingga proses joy full learning akan mewarnai dunia pendidikan dan peserta didik akan dengan senang hati melakukan diskusi, berbicara dari hati kehati dalam koridor pengembangan keilmuan. Oleh karena itu, maka secara filosofis pendidikan diartikan sebagai proses perolehan

8 Nurhadi and Senduk, Pembelajaran Konstektual Dan Penerapannya Dalam KBK, h. 34.

9 Syarifatul Marwiyah, "Konsep Pendidikan Berbasis Kecakapan Hidup," Jurnal Falasifa, Vol. 3, No. 1 (March 2012): h. 80-81. 
pengalaman belajar yang berguna bagi peserta didik, dan pengalaman tersebut diharapkan mampu mengembangkan potensi yang dimiliki peserta didik sehingga siap digunakan untuk memecahkan masalah-masalah yang muncul di dalam kehidupannya. Dengan dalih tersebut, maka kemudian faham konstruktivime ini dijadikan landasan filosofis dalam pengembangan pendidikan kecakapan hidup (Life Skill).

\section{Landasan Yuridis Life Skill}

Landasan yuridis pendidikan kecakapan hidup (lifeskill) dalam konteks bangsa Indonesia baru mengemuka pada era 2000an. Munculnya inisiasi tersebut merupakan sebuah usaha untuk meningkatkan mutu sumber daya manusia (SDM) bangsa ini dalam mengejar sebuah ketertinggalan di segala aspek kehidupan dari bangsa lain. Selain itu, adanya hal ini juga bertujuan untuk menyesuaikan dengan perubahan global serta perkembangan ilmu pengetahuan dan teknologi yang ada.

Oleh karenanya, pada tanggal 11 Juni 2003, bangsa Indonesia melalui DPR dan Presiden mengesahkan Undang-undang Sistem Pendidikan Nasional (Sisdiknas) yang baru. Munculnya Undang-undang tersebut merupakan pengganti dari Undang-undang Sisdiknas No. 2 Tahun 1989. Undang-undang Sisdiknas No. 20 Tahun 2003 tersebut terdiri atas 22 Bab dan 77 pasal, merupakan salah satu aplikasi dari tuntutan dari reformasi.

Adapun beberapa pasal yang mengatakan pendidikan kecakapan hidup adalah: ${ }^{10}$

(a) Pasal 3:

"Pendidikan nasional berfungsi mengembangkan kemampuan dan membentuk watak serta peradaban bangsa yang bermartabat dalam rangka mencerdaskan kehidupan bangsa, bertujuan untuk berkembangnya potensi peserta didik agar menjadi manusia beriman dan bertakwa kepada Tuhan YME, berakhlak mulia,

10 Tim Penyusun, Undang-Undang No.20 Tahun 2003 Tentang Sistem Pendidikan Nasional, (Yogyakarta: Media Wacana, 2003), h. 12-29. 
sehat, berilmu, cakap, kreatif, mandiri, dan menjadi warga Negara yang demokratis serta bertanggung jawab".

(b) Pasal 4, ayat 4:

"Pendidikan diselenggarakan dengan memberi keteladanan, membangun kemauan, dan mengembangkan kreativitas peserta didik dalam proses pembelajaran".

(c) Pasal 12 ayat $1 \mathrm{~b}$ :

"Setiap peserta didik pada setiap satuan pendidikan berhak mendapat pelayanan pendidikan sesuai dengan bakat, minat dan kemampuannya".

(d) Pasal 30 ayat 2:

"Pendidikan keagamaan berfungsi mempersiapkan peserta didik menjadi anggota masyarakat yang memahami dan mengamalkan nilai-nilai ajaran agamanya dan/atau menjadi ahli ilmu agama.

(e) Pasal 40 ayat 2a:

"Pendidik dan tenaga kependidikan berkewajiban menciptakan suasana pendidikan yang bermakna, menyenangkan, kreatif, dinamis dan dialogis".

Dan ayat $2 b$ :

"Pendidik dan tenaga kependidikan berkewajiban mempunyai komitmen secara professional untuk meningkatkan mutu pendidikan".

Melihat landasan yuridis diatas maka dapat dikatakan bahwa pendidikan kecakapan hidup merupakan pendidikan yang memberi bekal dasar dan latihan yang dilakukan secara benar kepada peserta didik tentang nilai-nilai kehidupan sehari-hari agar yang bersangkutan mampu, sanggup, dan terampil menjalankan kehidupannya yaitu dapat menjaga kelangsungan hidup dan perkembangannya di masa yang akan datang. Karena kecakapan hidup merupakan kemampuan, kesanggupan, dan keterampilan yang diperlukan oleh seseorang untuk menjalankan kehidupan dengan nikmat dan bahagia, serta mampu memecahkan persoalan hidup dan kehidupan tanpa adanya tekanan. 
Memperkaya akan landasan yuridis tentang pendidikan life skill secara universal, Djoko Hartono mengutip beberapa rekomendasi UNESCO tentang "Empat Pilar Pembelajaran" yang mesti diterapkan pada era globalisasi. Adapun keempat pilar tersebut meliputi: ${ }^{11}$

(1) Program pembelajaran yang diberikan hendaknya mampu memberikan kesadaran kepada masyarakat sehingga mau dan mampu belajar (learning know or learning to learn).

(2) Bahan belajar yang dipilih hendaknya mampu memberikan suatu pekerjaan alternatif kepada peserta didik (learning to do).

(3) Mampu memberi motivasi untuk hidup dalam era sekarang dan memiliki orentasi hidup ke masa depan (learning to be).

(4) Pembelajaran tidak cukup hanya diberikan dalam bentuk keterampilan untuk diri sendiri, tetapi juga keterampilan untuk hidup bertetangga, bermasyarakat, berbangsa dan hidup dalam pergaulan antar bangsa-bangsa dengan semangat kesamaan dan kesejajaran (learning to live together).

Berpijak pada landasan yuridis nasional dan landasan yuridis secara universal (rekomendasi UNESCO) sebagaimana terurai diatas, tersirat bahwa sama-sama memiliki tujuan dan fungsi untuk mengembangkan kemampuan dan membentuk watak serta peradaban bangsa yang bermartabat dalam rangka mencerdaskan kehidupan bangsa, yang bertujuan berkembangnya potensi peserta didik agar menjadi manusia yang beriman dan bertakwa kepada Tuhan Yang Maha Esa, beraklak mulia, sehat, cakap, kreatif, mandiri, dan menjadi warga negara yang demokratis serta bertanggung jawab, sesuai dengan apa yang menjadi tujuan dari pendidikan kecakapan hidup.

Lebih dari itu, secara eksplisit pendidikan life skill pada dasarnya mampu memberikan manfaat pribadi bagi peserta didik dan manfaat

11 Djoko Hartono, Pengembangan Life Skills Dalam Pendidikan Islam (Kajian Fondasional \& Operasional), Cet. ke-3, (Surabaya: Lembaga Kajian \& Penelitian ( LKP) Ponpes Mahasiswa, 2012), h. 25-26. 
sosial bagi masyarakat. Secara khusus bagi peserta didik, pendidikan life skill memiliki peran untuk dapat meningkatkan kualitas berpikir, kualitas kalbu, dan kualitas fisik. Sehingga hal tersebut akan berdampak pada peningkatan pilihan-pilihan dalam kehidupan secara individu, misalnya karir, penghasilan, pengaruh, prestise, kesehatan jasmani dan rohani, peluang, pengembangan diri, kemampuan kompetitif, dan kesejahteraan pribadi. Sementara itu dampak bagi masyarakat, pendidikan life skill dapat meningkatkan kehidupan yang maju dan madani dengan indikator-indikator adanya peningkatan kesejahteraan sosial, pengurangan perilaku destruksif sehingga dapat mereduksi masalah-masalah sosial, dan pengembangan masyarakat yang secara harmonis mampu memadukan nilai-nilai religi, teori, solidaritas, ekonomi, kuasa dan seni. ${ }^{12}$

\section{Pendidikan Life Skill: Menilik Konsep, Unsur dan Pola Penerapannya}

Berkaitan dengan konsep pendidikan lifeskill, Depdiknas mendeskripsikan kecakapan hidup (life skill) merupakan kecakapan dan kemampuan yang dimiliki oleh seseorang untuk mau dan berani menghadapi problema hidup dan kehidupan secara wajar tanpa merasa tertekan. Selanjutnya, orang tersebut secara proaktif dan kreatif mencari serta menemukan solusi sehingga akhirnya mampu mengatasinya. ${ }^{13}$ Sementara itu, Malik Fadjar dalam Slamet mendeskripsikan kecakapan hidup sebagai kecakapan untuk bekerja selain kecakapan untuk berorientasi ke jalur akademik. ${ }^{14}$ Sejalan dengan itu, Suryadi sebagaimana dikutip Tekad mengatakan keterampilan hidup meliputi beberapa kemampuan dasar, yakni ketrampilan sosial, vokasional, intelektual dan akademis. ${ }^{15}$

\footnotetext{
12 Marwiyah, "Konsep Pendidikan Berbasis Kecakapan Hidup," h. 84.

13 Depdiknas, Konsep Pendidikan Kecakapan Hidup (Life Skills Education), (Jakarta: Tim BroadBased Education, 2002).

14 Slamet PH, "Pendidikan Kecakapan Hidup: Konsep Dasar," http//www. Depdiknas.go.id, Jurnal, (n.d.).

15 Tekad Wahyono, "Program Keterampilan Hidup (Life Skill Program) Untuk Meningkatkan Kematangan Vokasional Siswa," ANIMA Indonesian Psychological Journal Vol. 17, no. 4 (2002): h. 387.
} 
Berkaitan dengan hal tersebut di atas, maka dapat dikatakan jika pendidikan life skill, idealnya mampu menginternalisasikan dan merefleksikan nilai-nilai (values) yang relistis (nyata) dalam kehidupan sehari-hari. Baik itu yang berkaitan dengan hal yang bersifat preservatif maupun progresif. Atas dasar inilah maka kemudian pendidikan meski dipandang perlu mengupayakan relevan dengan nilai-nilai kehidupan yang nyata. Upayaupaya ini pada akhirnya akan mendorong ranah pendidikan ke arah yang lebih kontekstual, realistis, dan tidak akan mencabut peserta didik dari akarnya. Dengan demikian, pendidikan akan lebih berguna dan bermakna bagi peserta didik. Bekenaan dengan hal ini, maka tidak berlebihan jika pendidikan life skill dapat diklasifikasikan kedalam dua jenis utama, yaitu: ${ }^{16}$

(1) Kecakapan hidup generik (generic life skill/GLS). Dari kecakapan hidup generic kemudian dibagi kedalam sub-sub, yaitu kecakapan personal (personal skill), dan kecakapan sosial (social skill). Untuk kecakapan personal mencakup kecakapan dalam memahami diri (self awareness skill) dan kecakapan berpikir (thinking skill). Sementara itu untuk kecakapan sosial mencakup kecakapan berkomunikasi (communication skill) dan kecakapan bekerjasama (collaboration skill).

(2) Kecakapan hidup spesifik (specific life skill/SLS). Pada bagian ini terdiri dari kecakapan akademik (academic skill) atau kecakapan intelektual, dan kecakapan vokasional (vocational skill). ${ }^{17}$

Berdasarkan uraian kecakapan hidup sebagaimana yang telah terurai diatas, maka kecakapan general maupun kecakapan spesifik dalam kehidupan yang riil akan berfungsi secara terpadu serta tidak terpisah-pisah, sehingga dengan peleburan tersebut menyatu menjadi tindakan individu yang melibatkan aspek fisik, mental, emosional dan intelektual.

${ }^{16}$ Depdiknas, Konsep Pengembangan Model Integrasi Kurikulum Pendidikan Kecakapan Hidup (Pendidikan Menengah), (Jakarta: Badan Penelitian dan Pengembangan Pusat kurikulum, 2007).

17 Kecakapan akademik terkait dengan bidang pekerjaan yang lebih memerlukan pemikiran atau kerja intelektual. Kecakapan vokasional terkait dengan bidang pekerjaan yang lebih memerlukan keterampilan motorik. Kecakapan vokasional terbagi atas kecakapan vokasional dasar (basic vocational skill) dan kecakapan vokasional khusus (occupational skill). 
Selanjutnya, sejalan dengan pesatnya perkembangan dan kemajuan keberadaan ilmu pengetahuan dan teknologi (Iptek) maka memunculkan inovasi-inovasi yang demikan bervariasi. Hal ini pada akhirnya berdampak pada manusia yang mesti belajar dari adanya perubahan yang terus menerus, dengan ketidak pastian, dan dengan ketidak mampuan untuk memeperhitungkan apa yang akan terjadi (unpredicatability). Sudah barang tentu, persoalan ini juga berdampak pada persoalan pendidikan, sejau manakah pendidikan mampu berperan mengantisipasi dan mengatasi problematika tersebut.

Problematika yang sedang "melanda" dunia pendidikan terus dideskripsikan secara "lantang" oleh John Vaizey. Dikatakan olehnya, bahwa setiap orang yang pernah menghadiri konferensi internasional ditahun-tahun terakhir pasti merasa terkejut akan banyaknya persoalan pendidikan yang memenuhi agenda. Dari sinilah terlihat jika makin lama makin jelas bahwa organisasi-organisasi internasional itu mencerminkan apa yang terjadi di semua negara di dunia. Sehingga hampir tidak ada satu Negara pun dewasa ini dimana pendidikan tidak merupakan topik utama yang diperdebatkan. ${ }^{18}$

Untuk itulah maka lembaga pendidikan dan pendidikan memiliki tugas dan tanggungjawab yang berat, yaitu membina peserta didik agar berani berdiri sendiri dan berusaha sendiri; maka kemampuan secara mandiri dan kritis (independent critical thinking) yang menjadi landasan mutlak untuk semuanya ini tidak hanya memerlukan kebebasan akademis, tetapi juga kebudayaan akademis yang merangsang berfikir mandiri dan kritis. Memperhatikan hal tersebut, maka pendidikan memiliki posisi strategis sekaligus menjadi sentral dalam proses pembangunan dan kemajuan untuk menanggapi tantangan masa depan. Konsekwensinya adalah pendidikan pada dewasa ini tidak lagi dapat mengharapkan peserta didik untuk mempelajari seluruh pengetahuan, namun harus dipilih pada bagian-bagian esensial yang menjadi dasar ataupun pondasinya.

${ }^{18}$ Muis Sadiman, Pendidikan Partisipatif, (Yogyakarta: Safiria Insania Press, 2004), h. 3. 


\section{Kesimpulan}

Pendidikan kecakapan hidup (life skill) menjadi sebuah keniscayaan untuk diterapkan di tengah "hingar-bingar" kompetisi global dan modernis sekarang ini. Pendidikan kecakapan hidup (life skill) menjadi pendekatan tersendiri untuk diaplikasikan, mengingat pendidikan jenis ini memiliki banyak manfaat bagi peserta didiknya, seperti kecakapan akademik, vokasional maupun yang lainnya. Yang menjadi persoalan adalah bagaimana lembaga pendidikan di berbagai sektor dapat mengaplikasikannya sehingga dapat membantu peserta didik untuk memperoleh life skill yang berguna dan bermanfaat serta dibutuhkan dalam kehidupan sehari-hari di masyarakat. Pendidikan life skill merupakan salah satu alternatif sebagai upaya mempersiapkan peserta didik agar memiliki sikap dan kecakapan hidup sebagai bekal bagi kehidupannya kelak melalui sebuah kegiatan pembelajaran yang aktif, kreatif dan menyenangkan.[]

\section{Daftar Pustaka}

Arifin, M. Ilmu Pendidikan Islam,. Jakarta: Bumi Aksara, 1996.

Depdiknas. Konsep Pendidikan Kecakapan Hidup (Life Skills Education),. Jakarta: Tim Broad-Based Education, 2002.

- - - Konsep Pengembangan Model Integrasi Kurikulum Pendidikan Kecakapan Hidup (Pendidikan Menengah),. Jakarta: Badan Penelitian dan Pengembangan Pusat kurikulum, 2007.

Hartono, Djoko. Pengembangan Life Skills Dalam Pendidikan Islam (Kajian Fondasional \& Operasional),. Cet. ke-3,. Surabaya: Lembaga Kajian \& Penelitian ( LKP) Ponpes Mahasiswa, 2012.

Hitami, Munzir. Mengonsep Kembali Pendidikan Islam,. Riau: Infinite Press, 2004.

Marwiyah, Syarifatul. "Konsep Pendidikan Berbasis Kecakapan Hidup,." JURNAL FALASIFA, Vol. 3, no. 1 (March 2012). 
Nurhadi, and Agus Gerrad Senduk. Pembelajaran KonstektualDanPenerapannya Dalam KBK,. Malang: Universitas Negeri Malang, 2004.

PH, Slamet. "Pendidikan Kecakapan Hidup: Konsep Dasar,." Http//www. Depdiknas.go.id.Jurnal, n.d.

Sadiman, Muis. Pendidikan Partisipatif.. Yogyakarta: Safiria Insania Press, 2004.

Suparno, Paul. Reformasi Pendidikan Sebuah Rekomendasi,. Jakarta: Kanisius, 2000.

Tim Penyusun. Undang-Undang No.20 Tahun 2003 Tentang Sistem Pendidikan Nasional,. Yogyakarta: Media Wacana, 2003.

Wahyono, Tekad. "Program Keterampilan Hidup (Life Skill Program) Untuk Meningkatkan Kematangan Vokasional Siswa,." ANIMA Indonesian Psychological Journal Vol. 17, no. 4 (2002). 